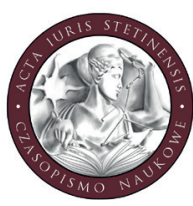

Acta. Furis Stetinensis

2020, No. 2 (Vol. 30), 73-87

ISSN: 2083-4373 e-ISSN: 2545-3181

DOI: $10.18276 /$ ais.2020.30-06

Maciej J. Nowak

Ph.D.

West Pomeranian University of Technology in Szczecin, Poland

Faculty of Economics

e-mail: macnowak@zut.edu.pl

ORCID ID: 0000-0001-6437-3226

\title{
Paulina Legutko-Kobus
}

Ph.D.

SGH Warsaw School of Economics, Poland

Collegium of Socio-Economics

e-mail: plegut@sgh.waw.pl

ORCID ID: 0000-0003-0380-8913

\section{Plans of protection tasks for Natura 2000 areas and local spatial policy}

\begin{abstract}
The aim of the paper is to define the key spatial conflicts regarding planning relations between the plans of protection tasks for Natura 2000 areas and local tools of spatial policy. The contents of all administrative court's decisions related directly to the plans of protection tasks for Natura 2000 areas are analysed. The judgements issued in 2010 - 2019 are taken into account. Sixteen of such judgements have been distinguished in the Central Database of Judicial Decisions of the Supreme Administrative Court (in principle, grouping all of such rulings). They are classified, and the allegations made in the cases, as well as the contents of specific plans of protection tasks, are analysed. A quantitative and qualitative analysis of the contents of the judicial decisions is conducted. Based on the analyses carried out, two main conclusions can be drawn up:
\end{abstract}


- $\quad$ on the occasion of spatial conflicts pending before administrative courts, related to the contents of plans of protection tasks for Natura 2000 areas, space users, as a rule, submit very similar objections to those concerning the direct tools of spatial policy;

- the contents of plans of protection tasks directly related to the contents of spatial policy tools are very often underdefined both in subjective and formal terms.

Keywords: plans of protection tasks, Natura 2000 areas, land management system

\section{Introduction}

Conducting spatial policy, especially at the local level, requires interdisciplinary depiction, definition of problems and proper implementation of solutions. A lack of understanding at the intersection of selected disciplines may prove to be a very frequent barrier. This also concerns legal, planning and environmental relations in the land management system. Furthermore, it is noticeable in the implementation of the aims and directions of nature protection in spatial policy tools. On the one hand, it concerns such forms of nature protection as e.g. national parks or nature reserves, yet, on the other hand, it concerns such a specific and important form of nature protection as Natura 2000 areas. The aim of the paper is to define the key spatial conflicts regarding the planning relations between the plans of protection tasks for Natura 2000 areas and local tools of spatial policy.

The local spatial policy in Polish reality should be understood as measures undertaken by municipal authorities aimed indirectly or directly at a specific spatial condition (specific manner of management thereof). Key local spatial policy tools include land management conditions and a directions study and local land management plans. The local spatial policy is significantly related to the issues of environment and nature protection. Terrains which are valuable in terms of environment and nature are subject to numerous restrictions in management (also determining the manner of managing neighbouring terrains). Moreover, nature protection tools (including plans of protection tasks), from their own (from the point of view of the sectoral land management system) perspective, influence both the actual management and the local spatial policy tools. The actual scope of this impact (despite statutory regulations) continues to be the object of doubts, and thus, spatial conflicts.

The sphere of interdependencies between Natura 2000 area management and the spatial policy is very broad. In this paper, the authors focus primarily on one subject matter related with the above issue: relations of plans of protective tasks 
for Natura 2000 areas and local spatial policy tools. In this context, in fact, bigger problems regarding the environment and nature protection in the land management system can be noticed in the broadest and clearest manner. Simultaneously, the authors concentrate on cases which, from the institutional perspective, have also been triggering the broadest spatial dilemmas and conflicts. This is, in fact, the manner of solving spatial conflicts that can constitute the factor determining improvement of the land management system in the future.

\section{Literature review}

The issues regarding the relation between the environment and nature protection ${ }^{1}$ and the spatial policy has constituted the object of numerous analyses. There is no doubt that proper depiction of these issues in the land management system causes a series of dilemmas primarily related to the coordination of aims and conditions depicted slightly differently in particular disciplines.

It concerns determining the general relation between the environment and nature protection and the spatial policy. There are no doubts that development of the environment should favour establishing spatial order. ${ }^{2}$ On the other hand, the spatial planning instruments should have a significant potential as environment protection tools. ${ }^{3}$ In this context, B. Szulczewska underlines that in the spatial planning process, the protection of areas of high natural values is provided by identification of the values and analysis of conditions of preservation thereof, as well as by formulating planning findings taking into account the aims of the protection (especially in the scope of admissible/excluded functions and principles, including restrictions in land development and management). ${ }^{4}$ Against this background, the role of environmental conflicts in land management, understood as conflicts

1 In literature on the subject, diverse terminology is used. Tomczak, A. and Sowa, D., Ochrona przyrody jako wyznacznik kształtowania przestrzeni, in: Górski, M. (ed.) Prawo ochrony przyrody a wolność gospodarcza, Lódź-Poznań 2011, pp. 423-424; Szulczewska, B., Planowanie przestrzenne jako instrument ochrony środowiska - wczoraj, dziś i jutro, in: Fetkowski, A. (ed.), W trosce o Ziemię. Ksiega ku czci Profesora Stefana Kozłowskiego, Lublin 2001, pp. 139-156; Szulczewska, B. et. al., How much green is needed for a vital neighborhood - in search for empirical evidence, "Land Use Policy" 2014, pp. 330-345.

2 Macias, A. and Bródka, S., Przyrodnicze podstawy gospodarowania przestrzenia, Warszawa 2014, p. 12.

3 Otawski, P., Ochrona środowiska jako wartość i cel planowania przestrzennego, in: Cieślak, Z. and Fogel, A. (eds.) Wartości w planowaniu przestrzennym, Warszawa 2010, p. 68.

4 Szulczewska, B., Planowanie przestrzenne jako instrument realizacji sieci ekologicznych: między teoriq a praktyka, in: Cieszewska, A. (ed.) Płaty i korytarze jako elementy struktury krajobrazu możliwości i ograniczenia koncepcji: Problemy ekologii krajobrazu - tom XIV, Warszawa 2004, 
regarding the condition, resources and availability of the environment, as well as threats thereto and forms of protection thereof, should be stressed. ${ }^{5}$ Environmental conflicts are one of the key conditions hindering taking the aims of environment protection into account in planning findings.

It is significantly contributed to by the current and, in many aspects, institutionally faulty land management system. ${ }^{6}$ The above causes spatial chaos, which also translates into concrete (countable) ecological losses. ${ }^{7}$ Therefore, there is a significant need for optimal care for environmental values from the perspective of public policy. From the perspective related to protection of the environment, local planning does not secure the environment, which can be manifested by, among others, an insufficient scope of the environmental part of local plans ${ }^{8}$ and insufficient consideration of environmental conditions in issuing decisions on the terms and conditions of development (while ignoring the issue of specific provisions). In the monograph providing a complex analysis of the aforementioned issues, I. Derucka indicates that in the context of current conditions, the role of planning tools can only be perceived as limiting threats to the environment. ${ }^{9}$ Nevertheless, even with such a point of view, the environment and nature scope of the spatial policy tools seems to be underspecified, the best example of which is the underspecified contents of the obligatory element of local land management plans, i.e. the principles of environment, nature and landscape protection. ${ }^{10}$

p. 55; Szulczewska, B., Planowanie przestrzenne a ochrona przyrody, "Studia Biura Analiz Sejmowych Kancelarii Sejmu" 2008, No. 10, pp. 57-79.

5 Przewoźniak, M. and Czochański, J., Przyrodnicze podstawy gospodarki przestrzennej. Ujęcie proekologiczne, Gdańsk-Poznań 2020, p. 21.

6 Nowak, M., Niesprawność władz publicznych a system gospodarki przestrzennej, "Polska Akademia Nauk. Komitet Przestrzennego Zagospodarowania Kraju. Studia” 2017, vol. CLXXV, pp. 214-225.

7 Chmielewski, T. et al., Ekologiczne i fizjonomiczne koszty bezładu przestrzennego, Warszawa 2018, pp. 103-107.

8 Baran-Zgłobicka, B., Środowisko przyrodnicze w zarządzaniu przestrzenią i rozwojem lokalnym na obszarach wiejskich, Lublin 2017, p. 394.

9 Derucka, I., Prawne gwarancje realizacji zadań ochrony środowiska $w$ procedurze planowania przestrzennego w gminach, Wrocław 2013, p. 243.

10 Aszkiełowicz, P., Uwzględnianie wymogów związanych z ochrona środowiska na przykładzie miejscowych planów zagospodarowania przestrzennego Olsztyna, "Metropolitan" 2018, No. 2 (10), p. 84; Ociepa-Kubicka, A., Rola planowania przestrzennego w zarzadzaniu ochrona środowiska, "Inżynieria i Ochrona Środowiska" 2014, No. 1, pp. 139-142; Nowak, M. and Kiepas-Kokot, A., Ograniczenia środowiskowe $w$ instrumentach zarzadzania przestrzeniq na szczeblu gminnym $w$ województwie zachodniopomorskim, "Studia Regionalne i Lokalne" 2014, No. 2, pp. 144-163; Nowak, M., Ochrona środowiska jako jeden z celów zarzq̨dzania przestrzeniq na szczeblu lokalnym i regionalnym, "Ekonomia i Środowisko" 2013, No. 1, pp. 193-205; Nowak, M., Postanowienia 
In the context directly referring to nature protection, it is worth indicating, in accordance with R. Giedych, that binding legal regulations do not allow a full, individualised scope of stipulating provisions regarding the forms of nature and, as a consequence, gradual disintegration of spatial planning and nature protection is observed. The majority of forms of nature protection have no aims guaranteeing implementation of nature protection aims in the spatial aspect. In the detailed dimension, premises for protected land management, to a great extent, are limited to bans. ${ }^{11}$ In this context, the plans of protection tasks for Natura 2000 areas should be analysed. ${ }^{12}$ From the perspective of this paper, the relation between these acts and spatial policy tools is crucial. The plan of protection tasks is established by the regional environment protection director in the form of an order (an act of local law). A premise for adopting this act is the necessity to maintain and restore the proper conservation status of natural habitats and species of plants and animals. In compliance with Article 28 par. 10 point 5 of the Act on the protection of nature, this plan must include: recommendation for changes in existing studies of conditions and directions of the land management of municipalities, local land management plans, voivodeship land management plans and land management plans for inland maritime waters, territorial waters and the exclusive economic zone regarding the elimination or limitation of internal or external threats, if they are necessary to maintain or restore the proper conservation status of natural habitats and species of plants and animals, for which the Natura 2000 area was indicated. According to A. Fogel, in the case of these types of areas, the issue of the significant negative impact on this area (analysed in a separate procedure) also plays a key role at the implementation stage. ${ }^{13}$ However, there are no doubts that in the dimension regarding the discussed issues, it seems crucial to assess the relation between plans of protection tasks for Natura 2000 areas (universally binding acts) and local spatial

planów miejscowych a ochrona środowiska w gminach cennych przyrodniczo, "Samorząd Terytorialny" 2015, No. 11, pp. 35-44.

11 Giedych, R., Ochrona przyrody w polityce przestrzennej miast, "Polska Akademia Nauk. Komitet Przestrzennego Zagospodarowania Kraju. Studia” 2018, vol. CXC, pp. 70-109.

12 Objectives related to Natura 2000 areas do not raise serious doubts and were clearly expressed in the scope related to the subject matter discussed herein, among others in the following publications: Habuda, A., Obszary Natura 2000 w prawie polskim, Warszawa 2013, pp. 27-38; Radecki, W., Ustawa o ochronie przyrody. Komentarz, Warszawa 2012, pp. 204-207; Federczyk, W. et al., Prawo ochrony środowiska w procesie inwestycyjno - budowlanym, Warszawa 2015, pp. 223-232.

13 Fogel, A., Prawna ochrona przyrody w lokalnym planowaniu przestrzennym, Warszawa 2011, p. 147. 
policy tools. It is especially necessary to determine how the aforementioned "indications" are formulated. The hitherto analyses ${ }^{14}$ imply that:

- in some plans, indications are not specified precisely enough; not to a specific spatial policy tool, but generally;

- sometimes the statutory scope is exceeded in formulating indications (by addressing them to other acts);

- the possible scope of spatial policy tools is exceeded;

- some indications have been formulated too generally.

The scope of spatial conflicts directly related with contesting this part of protection plans before administrative courts is not too broad (especially if compared with the scope of analogous spatial conflicts concerning e.g. local land management plans). ${ }^{15}$ Nonetheless, important conclusions can also be drawn up on these grounds.

One of the possibilities of preventing such situations seems to be participation (socialisation) within the framework of drawing up and implementing plans of protection tasks for Natura 2000 areas. Stakeholders who should be included in the process are, above all: local government units, the voivodeship office (often including the Voivodeship Conservator of Monuments), the forest inspectorate and entities supervising private forests, non-governmental organisations (including ecological), local associations and action groups, land owners and users, scientists conducting research on a given terrain, local leaders (formal and informal) and other persons interested in the area. As underlined by A. Haładyj, socialisation of the process of drawing up and adopting plans of protection tasks results in positive effects provided that it is properly planned, i.e. the boundary conditions concerning the actual inclusion of stakeholders are met. It is crucial for the result of the process that participating stakeholders have knowledge on the consequences of undertaken findings and ensure inclusion of commonly established positions and solutions in the adopted plan. ${ }^{16}$ Good practices in this scope concern appointment of the Local Cooperation Team (it is important to select the team members who should reflect the characteristics of the Natura 2000 area) or operation of an information and

14 Nowak, M., Plany zadań ochronnych dla obszarów Natura 2000 jako instrument zarządzania środowiskiem - kluczowe problemy, "Budownictwo i Architektura" 2014, No. 13 (1), pp. 7-14.

15 See: e.g. Nowak, M. et. al., Orzeczenia sąów administracyjnych w systemie gospodarki przestrzennej - perspektywa funkcjonalna i realizacyjna. Studium przypadku województwa mazowieckiego, "Samorząd Terytorialny" 2020, No. 7-8, pp. 109-128.

16 Haładyj, A., Działania faktyczne w prawie ochrony środowiska na przykładzie uspołeczniania planów zadań ochronnych dla obszaru Natura 2000, "Roczniki Nauk Prawnych" 2012, No. 10, pp. 156-157. 
communication platform. ${ }^{17}$ Benefits that can result from participation and then translate into minimising spatial conflicts are related to: an increase in knowledge on the possibilities of development based on Natura 2000 areas, change in perceiving protective measures and perception thereof as a catalyst of local activity and development and, finally, changing attitudes to institutions such as RDEP. It should be mentioned that participation, related to the establishment and adoption of plans of protection tasks for Natura 2000 areas, fits into the wider context of participatory management of nature protection, i.e. a process which is rarely fully implemented in Poland, which results from poor social awareness in this scope and little faith in including commonly established positions in the final documents (and in broader terms - in agency). ${ }^{18}$

Simultaneously, it should be noticed that one of the main barriers in active inclusion of stakeholders in decision-making processes concerning management of Natura 2000 areas and then translating implementation thereof into planning acts consists in the weakness of the participation processes and low level of social capital in Poland. ${ }^{19}$ All of these factors have a direct impact on causing spatial conflicts and the course thereof.

\section{Plans of protection tasks for Natura 2000 areas challenged before administrative courts in the years $2010-2019$}

Another research stage consisted in analysing the contents of all administrative courts' decisions related directly to the plans of protection tasks for Natura 2000 areas. It was decided that cases concerning the contents of indicated plans which ended before administrative courts can be considered as those on occasion of which spatial conflicts were disclosed to the broadest extent (irrespective of the final ruling). The judgements issued in 2010 - 2019 were taken into account. Sixteen of such judgements were distinguished in the Central Database of Judicial Decisions of the Supreme Administrative Court (in principle, grouping all such rulings). Judicial decisions (only valid) were searched by "plans of protection tasks" (referring only to the sentence of a judicial decision). Sixteen judicial decisions of administrative courts were separated (one judgement of the Supreme Administrative Court was

17 RDOŚ, Plany zadań ochronnych w pigułce na przykładzie 11 obszarów Natura 2000 w województwie śląskim, Katowice 2014, pp. 6-7.

18 Luzar-Błaż, K., et al., Partycypacja społeczna w zarządzaniu terenami chronionymi na przykładzie obszaru Natura 2000 - Dolinki Jurajskie, "Wieś i Rolnictwo" 2017, No. 2, p. 50.

19 Cf. e.g. Nowakowska, A. et al., Od rehabilitacji do włączenia społecznego - współczesne ujęcie procesów rewitalizacji, Warszawa 2019, pp. 50-52. 
included separately). The verification period (2010 - 2019) was dictated by, on the one hand, the need to collect data for a longer period of time (especially with a small number of cases concerning plans of protection tasks). On the other hand, a longer period was not selected due to the risk of diverse legal regulations and ruling practices. Due to the implementation of the paper's objective, there are no doubts that the data in question, subject to analysis, can refer to the current state. Judgments stating the invalidity of a given act or rejecting a complaint are undoubtedly especially important. These allow verification of the role of administrative courts both in the context of nature protection issues and the land management system to the broadest extent.

Table 1. Classification of judgments of administrative courts concerning plans of protection tasks from the perspective of directions of rulings

\begin{tabular}{|l|c|}
\hline \multicolumn{1}{|c|}{ Ruling } & Number \\
\hline Declaration of invalidity & 1 \\
\hline Dismissal & 4 \\
\hline Rejection & 7 \\
\hline Annulment & 4 \\
\hline
\end{tabular}

Source: author's own study.

Table 1 implies that there are relatively few litigations pending at administrative courts with regard to the contents of plans of protection tasks for Natura 2000 areas. $^{20}$ This conclusion is especially confirmed when the indicated results are compared to the number of cases before courts concerning local land management plans or studies of conditions and directions of land management. Spatial conflicts are disclosed primarily at the stage of applying spatial policy tools. The above does not change the fact that plans of protection tasks for Natura 2000 areas also generate certain problems. Some of these are reflected at a later stage. However, it is worth analysing certain regularities related to these tools.

Usually, the complaints were brought by owners of specific properties. In two cases, the plaintiffs were municipalities, and in another two cases - State Forests (i.e. stakeholders should gain knowledge on the provisions of plans and consequences thereof at the stage of drawing up documents). It should also be underlined that the

20 File numbers of judicial decisions are the following: II SA/Ol 486/19, II SA/Gd 522/18, II SA/Gd 517/18, II SA/Bk 315/18, II SA/Bk 7/18, II SA/Op 23/17, II SA/Ol 1323/16, II SA/Ol 756/15, II SA/ Lu 408/15, II SA/Lu 409/15, II SA/Rz 684/15, II SA/Rz 689/15, II SA/Lu 164/15 II SAB/Ol 168/12, II OSK 1924/12, IV SA/Wa 1772/11. 
minority of cases ended with a ruling directly related to the verification of provisions of a specific plan. The complaints were predominantly rejected or annulled (which does not change the fact that there were also spatial conflicts on this occasion).

Table 2. Main charges raised against plans of protection tasks for Natura 2000 areas addressed in cases that ended with a declaration of invalidity of those acts or dismissing the complaints

\begin{tabular}{|l|l|}
\hline \multicolumn{1}{|c|}{ Direction of the judicial decision } & \multicolumn{1}{c|}{ Key charges } \\
\hline Declaration of invalidity & - excessive limitations in development \\
& possibilities; \\
- & exceeding the statutory scope (and the \\
& scope stipulated in regulations) for plans of \\
& protection of Natura 2000 areas. \\
\hline Dismissal & - unjustified bans and restrictions in \\
& development/conducting economic activity; \\
& - a lack of analysis of the terrain before \\
& introducing restrictions (including a lack \\
& of examination of the purposefulness and \\
& proportionality of restrictions); \\
& - introduction of "secret bans" of a universally \\
& binding character. \\
\hline
\end{tabular}

Source: author's own study.

In many aspects, the charges concerning plans of protection tasks for Natura 2000 areas remind dominant charges concerning local land management plans in analogous cases. Above all, the complaints of owners of properties indicated the exceeding of possible boundaries of interference and unjustified restriction of the right of ownership (Table 2). In such cases, the discussion concerning the actual scope of the right of ownership, as well as the manner of justifying interference (including the quality of used analyses) is open. In cases where the plaintiffs presented the above arguments, they also connected them with exceeding the statutory scope of protection plans. It should be simultaneously underlined that these charges were of very limited use in the analysed case.

The contents of indications to planning acts included in the plans of protection tasks for Natura 2000 areas, which (in compliance with Tables 1-2) caused the largest spatial conflicts, were also analysed. Table 3 implies that the subject indications copy previously diagnosed errors. Above all, they are very often not sufficiently precise. This hinders effective challenging thereof; however, at the same time, this contributes to easier challenging of local land management plans adopted on the grounds thereof. 
Table 3. Selected indications for changes in planning acts included in the plans of protection tasks for Natura 2000 areas causing spatial conflicts

\begin{tabular}{|c|c|}
\hline $\begin{array}{l}\text { Natura } 2000 \text { area } \\
\text { which the indications concern }\end{array}$ & Contents of selected indications \\
\hline $\begin{array}{l}\text { Masurian Refuge of the Baranowo } \\
\text { Turtle }\end{array}$ & $\begin{array}{l}\text { - introduction of the decision regarding key areas for } \\
\text { the protection of breeding sites of the European pond } \\
\text { turtle - } 500 \mathrm{~m} \text { around places of permanent residence of } \\
\text { European pond turtles - protecting these places against } \\
\text { new residential buildings at a distance from existing } \\
\text { buildings that can have a negative impact on the objects } \\
\text { of protection in the Natura } 2000 \text { area. }\end{array}$ \\
\hline Białowieża Forest & $\begin{array}{l}\text { - allowing various types of transformations of functions } \\
\text { of the terrains and supplementing them where it does } \\
\text { not cause an inconvenience for surrounding residential } \\
\text { buildings and the environment. }\end{array}$ \\
\hline Sandomierz Forest & $\begin{array}{l}\text { - to introduce on the lands with the recognised habitat } \\
\text { of birds the provision on maintenance in the hitherto } \\
\text { manner of land management. Development only in } \\
\text { places not colliding with the birds' protection. }\end{array}$ \\
\hline Uroczyska Roztocza Wschodniego & $\begin{array}{l}\text { - ban on location of a new building at a distance less than } \\
30 \mathrm{~m} \text { from breeding sites; } \\
\text { - maintenance of wildlife corridors allowing preservation } \\
\text { of the coherence of the Natura } 2000 \text { network - } \\
\text { structures such as afforestation, avenues and rows of } \\
\text { trees should be maintained during update. }\end{array}$ \\
\hline Kamień & $\begin{array}{l}\text { - principles of development and infrastructure of the } \\
\text { grounds - recreational and leisure buildings and } \\
\text { devices should have small capacity and refer with its } \\
\text { architectonic form and detail to traditional forms and } \\
\text { should fit the environment. }\end{array}$ \\
\hline Ostoja Warmińska & $\begin{array}{l}\text { - issuance of permits for location of wind farms in the } \\
\text { area of Ostoja should be withheld; } \\
\text { - promotion of generating other forms of energy: solar, } \\
\text { biogas works; } \\
\text { - annual and multi-annual energy crops (e.g. willow, birch, } \\
\text { poplar) are not recommended. }\end{array}$ \\
\hline
\end{tabular}

Source: author's own study.

Issues concerning the referred indications (including the manner of expressing them) illustrate in more detail the dilemmas occurring in the land management system very well. One of the key issues is the lack of sufficient integration of the spatial policy with other areas of activity (undertaken on a local, regional and central 
level). ${ }^{21}$ As a consequence, it is also manifested with the fact that the postulates concerning the spatial policy (included in other policies' tools) are sometimes, from the perspective of the land management system, quite chaotic and imprecise both in subjective and formal terms.

Furthermore, the cases pending before administrative courts regarding agreements on local projects of land management plans by regional environment protection directors were verified in the scope of compliance with the aims of forms of nature protection (Natura 2000 area, landscape parks and protected landscape areas). They should be treated as a supplement to previous analyses allowing one to more broadly analyse the context of relations between the land management system and nature protection.

Table 4. Characteristics of administrative court cases concerning refusals to agree on projects of local plans for forms of nature protection in the years 2010-2019

\begin{tabular}{|c|c|}
\hline Criterion & Characteristics \\
\hline $\begin{array}{l}\text { The number of cases in which the } \\
\text { refusal to agree on projects was } \\
\text { upheld by courts }\end{array}$ & 11 \\
\hline $\begin{array}{l}\text { Limitations constituting the object of } \\
\text { the conflict }\end{array}$ & $\begin{array}{l}\text { - ban on the liquidation of afforestation - contrary to } \\
\text { the service purpose of the terrain specified in the plan } \\
\text { (and elements of management thereof); } \\
\text { - housing development provided for in the plan will } \\
\text { infringe upon the ban on locating buildings included } \\
\text { in the acts for forms of nature protection; } \\
\text { - admission under the plan of the possibility to } \\
\text { perform fencing below } 2.20 \mathrm{~m} \text { is related to the } \\
\text { significant negative impact for Natura } 2000 \text { areas; } \\
\text { - admission of a detrimental exploitation of aggregate; } \\
\text { - replacing agricultural use with service use will have } \\
\text { a negative impact on the specific forms of nature } \\
\text { protection; } \\
\text { - agreements regarding active protection of ecosystems } \\
\text { and related collision in the scope of development } \\
\text { provided for in the local plan - a large hotel complex; } \\
\text { - ban on locating buildings in a } 100 \text { metre-wide patch } \\
\text { of land from the coastline of rivers, lakes and other } \\
\text { water reservoirs, with the exception of water devices } \\
\text { and buildings, with the purpose of conducting } \\
\text { rational agricultural, forestry or fishery management. }\end{array}$ \\
\hline
\end{tabular}

21 Markowski, T., Zintegrowane planowanie rozwoju, in: Kukliński, A. and Woźniak, J. (eds.), Przyszłość wolności, wymiar krajowy - regionalny - międzynarodowy, Kraków 2014, pp. 335-367. 


\begin{tabular}{|c|c|}
\hline Criterion & Characteristics \\
\hline $\begin{array}{l}\text { The number of cases in which courts } \\
\text { questioned the refusal of agreement } \\
\text { on projects }\end{array}$ & 7 \\
\hline $\begin{array}{l}\text { Limitations constituting the object of } \\
\text { the conflict }\end{array}$ & $\begin{array}{l}\text { - too broad a ban on development (unjustified with the } \\
\text { needs related to nature protection); } \\
\text { - improper qualification by the approving authorities } \\
\text { of the negative impact of investment on the forms of } \\
\text { nature protection. }\end{array}$ \\
\hline
\end{tabular}

Source: author's own study.

On the basis of Table 4, it can be indicated how spatial conflicts between the environmental and nature area (represented by the approving authority) and the investment area (represented in this case by municipal authorities responsible for drawing up a local plan) looked like. Nevertheless, this perspective is different from the one included in Tables 1-3. In Table 4 (in the summary), the key directions of specific, expressed positions were presented; therefore, they should be considered representative for the subject matter discussed therein. It can be assumed that the key dilemma again comes down to the scope of possible limitations in development. The circumstances related to the admissible scope of development (despite environmental and nature limitations) constitute the basis of disputes and doubts, not only in cases concerning plans of protection tasks. This is a broader list of barriers and dilemmas in the land management system. Apart from the determination of proportionality of admissible planning interference, the concurrence of bans included in projects of local plans is also verified in the indicated judicial decisions with bans included in acts concerning particular forms of nature protection. It should be underlined that local plans which are not precisely expressed also constitute an object of conflicts.

\section{Conclusions}

The assessment of plans of protection tasks requires underlining the characteristics thereof. In the construction of these acts, it is required to take into consideration both conditions related to the nature protection and planning conditions, as well as allowing participation. There is a problem with transferring the above into the legal sphere. On the basis of the conducted analyses, two main conclusions can be drawn: 
- on the occasion of spatial conflicts related to the contents of plans of protection tasks for Natura 2000 areas pending before administrative courts, space users, as a rule, raise objections very similar to those concerning the direct tools of spatial policy (e.g. local land management plans);

- the contents of plans of protection tasks directly referring to the contents of spatial policy tools are very often underdefined both in subjective and formal terms. This is an expression of a broader issue of the land management system, especially its lack of sufficient integration with other policies.

With regard to the second conclusion, it is worth indicating that (as has been indicated in the literature review) the postulated direction of activities comprises the integration of the policy of development that is currently missing. Obviously, there are relations between diversified development spheres (which can be treated as origins of such an integration), and they constitute the object of research. Nevertheless, the contents of plans of protection tasks indicated in the underdefined results (from the perspective of the land management system) confirm the theses and the lack of sufficient integration of policies of development.

From the point of view of spatial conflicts, in the scope analysed herein, there is a decidedly stronger relation between the environment and nature protection sphere than that guaranteed by the currently binding legal regulations. Nevertheless, the particular wording of selected regulations will not be the only problem. The lack of integration of policies of development generates, and will continue to generate to a greater extent, similar situations (also deepening spatial chaos, as well as limiting the flexibility of planning). It will also involve negative consequences for the environment and nature protection sphere, resulting in the lack of the possibility of comprehensive protection of the environmental and natural values of terrains adequate to their needs.

\section{References}

Aszkiełowicz, P., Uwzględnianie wymogów związanych z ochrona środowiska na przykładzie miejscowych planów zagospodarowania przestrzennego Olsztyna, "Metropolitan" 2018, No. 2 (10).

Baran-Zgłobicka, B., Środowisko przyrodnicze w zarządzaniu przestrzenia i rozwojem lokalnym na obszarach wiejskich, Lublin 2017.

Chmielewski, T. et al., Ekologiczne i fizjonomiczne koszty bezładu przestrzennego, Warszawa 2018.

Derucka, I., Prawne gwarancje realizacji zadań ochrony środowiska w procedurze planowania przestrzennego w gminach, Wrocław 2013. 
Federczyk, W. et al., Prawo ochrony środowiska $w$ procesie inwestycyjno-budowlanym, Warszawa 2015.

Fogel, A., Prawna ochrona przyrody w lokalnym planowaniu przestrzennym, Warszawa 2011.

Giedych, R., Ochrona przyrody w polityce przestrzennej miast, "Polska Akademia Nauk. Komitet Przestrzennego Zagospodarowania Kraju. Studia” 2018, Vol. CXC, Warszawa 2018.

Habuda, A., Obszary Natura 2000 w prawie polskim, Warszawa 2013.

Macias, A. and Bródka, S., Przyrodnicze podstawy gospodarowania przestrzenia, Warszawa 2014.

Haładyj, A., Działania faktyczne w prawie ochrony środowiska na przykładzie uspołeczniania planów zadań ochronnych dla obszaru Natura 2000, "Roczniki Nauk Prawnych" 2012, No. 1.

Luzar-Błaż, K. et al., Partycypacja społeczna w zarządzaniu terenami chronionymi na przykładzie obszaru Natura 2000 - Dolinki Jurajskie, "Wieś i Rolnictwo" 2017, No. 2 (175).

Markowski, T., Zintegrowane planowanie rozwoju, in: Kukliński, A. and Woźniak, J. (eds.), Przyszłość wolności, wymiar krajowy-regionalny-międzynarodowy, Kraków 2014.

Nowak, M., Niesprawność władz publicznych a system gospodarki przestrzennej, "Polska Akademia Nauk. Komitet Przestrzennego Zagospodarowania Kraju. Studia” 2017, vol. CLXXV.

Nowak, M., Ochrona środowiska jako jeden z celów zarządzania przestrzenią na szczeblu lokalnym i regionalnym, "Ekonomia i Środowisko" 2013, No. 1.

Nowak, M. and Kiepas-Kokot, A., Ograniczenia środowiskowe w instrumentach zarzqdzania przestrzenia na szczeblu gminnym w województwie zachodniopomorskim, "Studia Regionalne i Lokalne" 2014, No. 2.

Nowak, M. et al., Orzeczenia sądów administracyjnych w systemie gospodarki przestrzennej-perspektywa funkcjonalna i realizacyjna. Studium przypadku województwa mazowieckiego, "Samorząd Terytorialny" 2020, No. 7-8.

Nowak, M., Plany zadań ochronnych dla obszarów Natura 2000 jako instrument zarządzania środowiskiem - kluczowe problemy, "Budownictwo i Architektura" 2013, No. 13 (1).

Nowak, M., Postanowienia planów miejscowych a ochrona środowiska w gminach cennych przyrodniczo, "Samorząd Terytorialny" 2015, No. 11.

Nowakowska, A. et al., Od rehabilitacji do włączenia społecznego - współczesne ujęcie procesów rewitalizacji, Warszawa 2019.

Szulczewska, B. et al., How much green is needed for a vital neighborhood - in search for empirical evidence, "Land Use Policy" 2014.

Szulczewska, B., Planowanie przestrzenne a ochrona przyrody, "Studia Biura Analiz Sejmowych Kancelarii Sejmu” 2008, No. 10. 
Szulczewska, B., Planowanie przestrzenne jako instrument ochrony środowiska - wczoraj, dziś i jutro, in: Fetkowski, A. (ed), W trosce o Ziemię. Księga ku czci Profesora Stefana Kozłowskiego, Lublin 2001.

Szulczewska, B., Planowanie przestrzenne jako instrument realizacji sieci ekologicznych: między teoria a praktyka, in: Cieszewska, A. (ed.), Płaty i korytarze jako elementy struktury krajobrazu - możliwości i ograniczenia koncepcji: Problemy ekologii krajobrazu - tom XIV, Warszawa 2004.

Ociepa-Kubicka, A., Rola planowania przestrzennego w zarządzaniu ochrona środowiska, "Inżynieria i Ochrona Środowiska" 2014, No. 1.

Otawski, P., Ochrona środowiska jako wartość i cel planowania przestrzennego, in: Cieślak, Z. and Fogel, A. (eds.), Wartości w planowaniu przestrzennym, Warszawa 2010.

Przewoźniak, M. and Czochański, J., Przyrodnicze podstawy gospodarki przestrzennej. Ujęcie proekologiczne, Gdańsk-Poznań 2020.

Radecki, W., Ustawa o ochronie przyrody. Komentarz, Warszawa 2012.

RDOŚ, Plany zadań ochronnych w pigułce na przykładzie 11 obszarów Natura 2000 w województwie śląskim, Katowice 2014, pp. 6-7.

Tomczak, A. and Sowa, D., Ochrona przyrody jako wyznacznik kształtowania przestrzeni, in: Górski, M. (ed.), Prawo ochrony przyrody a wolność gospodarcza, Łódź-Poznań 2011.

\section{CITATION}

Nowak, M.J., and Legutko-Kobus, P., Plans of protection tasks for Natura 2000 areas and local spatial policy, "Acta Iuris Stetinensis" 2020, No. 2 (Vol. 30), 73-87,

DOI: 10.18276/ais.2020.30-06. 